\title{
Covid-19: Still Counting the Costs
}

\author{
Alamin Alkundi* and Rabiu Momoh
}

\section{William Harvey Hospital, Ashford, Kent, United Kingdom}

Not many diseases in the history of mankind have left man with much confusion as to how best to get over them as COVID-19 has posed. For many years to come, many would reckon with the impact that the COVID-19 pandemic has had on life as we know it. While the increased ease of travel and the gains of globalization were being acknowledged, COVID-19 soon became somewhat a 'reality checker'. The pandemic has further emphasized the important role that microbes play in our existence, and many have awakened to this [1].

COVID-19 has achieved a "man-of-the-year" status, claiming more than a million lives already (and still counting) and leaving many with reminder effects [2]. In an unprecedented move, nations of the world shut borders in a quest to control this deadly virus. Almost all aspects of human endeavours were affected by this pandemic, and many sectors have had to make modifications to accommodate this.

The culture of distancing or separation became the way to go to avoid contracting this highly infectious virus [3]. The mental health of people started to become an issue from prolonged isolation and a plunge in available resources to them [4]. Restricted community health support services during lockdown measures did put a strain on those dependent on these, including patients with diseases like chronic obstructive pulmonary disease, heart failure, and those needing non-invasive ventilation within the community. Many hospital clinic services that required physical attendance were stopped in a lockdown move to control the virus. One significant gain from the challenges that this virus posed is the realization that many services could be conducted electronically or virtually, and many have geared up to this. A lot of businesses and hospital services have started to explore telephone and video consultations in the care of out-patients and in triaging patients and their conditions prior to hospital visits [5]. Modifications to hospital care services that required close personnel contacts to patients were made, especially in caring for eye, dental, ear, nose, and throat conditions.

The opportunity cost to preventing infection rates and deaths due to the COVID-19 virus through lockdown moves deployed by governments of nations and restricted physical hospital clinic services is the potential risk of delivering suboptimal services to patients with chronic disease conditions as alluding to above and progression of their disease when next they are physically evaluated [6]. Modifications are being made to accommodate hospital intervention services that re- quire aerosol generation (including endoscopies and general anesthetic delivery) [7].

We are still faced with the impact of a virus that has been known to cause damage to many organ systems in the body, chief among which is its effect on the lungs, causing acute respiratory distress syndrome (ARDS). Those who have survived the severe ARDS complication of this virus required rehabilitation, as many have noted the scarring and reduced lung function that has accompanied this virus. COVID-19-related gastroenteritis, nephritis, pancreatitis, encephalitis, and myocarditis have all been described in the literature about this virus [8]. Chronic fatigue syndrome has been described in those who have survived the severe forms of this viral infection, and this potentially could reduce working hours that could have helped many economies [9].

The economic cost to the health sector and governments of nations at curbing the impact of this virus is enormous. Funds have been spent on testing for this virus, providing personal protective equipment, educating the public, and making hospitals safe for users. More funds will be spent to ensure follow-up services to those who have survived the severe forms of this viral infection in terms of follow-up radiological studies, lung function tests, and echocardiography, among others [10].

The challenges that this pandemic has posed to our social lives have been enormous, and its manifestations have evolved with government regulations (aimed at controlling this virus). From the separation of infected loved ones needing hospital visits, to those separated by travel regulations, and many more experiences, the impact of this virus continues to define many lives and their experiences this year.

\section{Acknowledgement}

The author wishes to acknowledge all the staff members of the William Harvey hospital for their continued effort in the care.

*Corresponding author: Alamin Alkundi, William Harvey Hospital, Ashford, Kent, United Kingdom, Tel: +447427157067

Accepted: November 10, 2020

Published online: November 12, 2020

Citation: Alkundi A, Momoh R (2020) Covid-19: Still Counting the Costs. J Healthcare 3(1):43-44

Copyright: (c) 2020 Alkundi A, et al. This is an open-access article distributed under the terms of the Creative Commons Attribution License, which permits unrestricted use, distribution, and reproduction in any medium, provided the original author and source are credited. 


\section{Funding statement}

None required of patients despite the challenges posed by the COVID-19 pandemic.

\section{Authors Contribution Statement}

Both authors contributed equally towards this document.

\section{References}

1. Jordan P, Mitch S (2020) Surging solidarity: Reorienting ethics for pandemics.

2. (2020) Covid-19 coronavirus pandemic.

3. Lawrence OG, Eric AF, Sarah AW (2020) Responding to COVID-19: How to navigate a public health emergency legally and ethically. Hastings Cent Rep 50: 8-12.

4. Rajiv T (2020) COVID-19 and mental health: Preserving humanity, maintaining sanity, and promoting health. Asian J Psychiatr 51: 102256.
5. Judd EH, Brendan GC (2020) Virtually perfect? Telemedicine for COVID-19. N Engl J Med 382: 1679-1681.

6. (2020) The Impact of the COVID-19 pandemic on noncommunicable disease resources and services: Results of a rapid assessment. WHO.

7. Brittany EH (2020) High-risk aerosol-generating procedures in COVID-19: Respiratory protective equipment considerations. 163.

8. Suruchi G, Mandeep G, Nidhi P, et al. (2020) Unravelling the mystery of COVID-19 cytokine storm: From skin to organ systems. e13859.

9. Angelo C, Roberto B, Francesco L et al. (2020) Persistent symptoms in patients after acute COVID-19. JAMA 324: 603-605.

10. Trisha G, Matthew K, Maria B et al. (2020) Management of postacute COVID-19 in primary care. BMJ 370: 3026.

DOI: $10.36959 / 569 / 460$

Copyright: (C) 2020 Alkundi A, et al. This is an open-access article distributed under the terms of the Creative Commons Attribution License, which permits unrestricted use, distribution, and reproduction in any medium, provided the original author and source are credited. 